\title{
Serological survey of Toxoplamosis in South American coatis (Nasua nasua) in Tietê Ecological Park, São Paulo, SP, Brazil
}

\section{Inquérito sorológico da Toxoplasmose em quatis (Nasua nasua) do Parque Ecológico do Tietê, São Paulo, SP, Brasil}

\author{
Jéssica França MAIA ${ }^{1}$; Solange Maria GENNARI ${ }^{2}$; Liliane MILANELO ${ }^{3}$; Haroldo Ryoiti FURUYA ${ }^{3}$; Vanessa \\ Aparecida Feijó SOUZA ${ }^{1}$; Sérgio Netto VITALIANO ${ }^{1,2}$ \\ ${ }^{1}$ Faculdades Metropolitanas Unidas, Curso de Medicina Veterinária, São Paulo - SP, Brazil \\ ${ }^{2}$ Universidade de São Paulo, Faculdade de Medicina Veterinária e Zootecnia, Departamento de Medicina Veterinária Preventiva e Saúde \\ Animal, São Paulo - SP, Brazil \\ ${ }^{3}$ Centro de Recuperação de Animais Silvestres, Parque Ecológico do Tietê (CRAS-PET), Engenheiro Goulart - SP, Brazil
}

\begin{abstract}
Toxoplasma gondii is an obligate intracellular protozoan parasite that causes toxoplasmosis in humans, domestic animals and wild animals. Although there is serological evidence of $T$. gondii infection in wild animals, little is known about the role of wildlife in the epidemiological chain of this parasite. The South American coati (Nasua nasua) is an omnivorous species capable of adaptation to different environments. It can be found throughout Brazil, and in anthropized environments it can come into close contact with domestic animals. The present study found occurrences of $T$. gondii antibodies in South American coatis living in the Tietê Ecological Park, in the municipality of São Paulo, Brazil, through the modified agglutination test (MAT). In total, 99 samples were obtained and $70.70 \%(n=70)$ were positive for anti- $T$. gondii antibodies, with titers that ranged from 50 to 3200. The data from this study indicate that South American coatis are exposed to this parasite.
\end{abstract}

Keywords: Serology. MAT. Wildlife. Toxoplasmosis.

\section{Resumo}

Toxoplasma gondii é um protozoário parasita intracelular obrigatório que causa a toxoplasmose em humanos, animais domésticos e selvagens. Apesar das evidências sorológicas da infecção por T. gondii em animais selvagens, pouco se sabe sobre o papel da vida selvagem na cadeia epidemiológica deste parasito. Os quatis (Nasua nasua) são uma espécie onívora capaz de se adaptar em diferentes ambientes. Eles são encontrados em todo território brasileiro, e em ambientes antropizados podem apresentar um contato próximo com animais domésticos. O presente estudo verificou a ocorrência de anticorpos anti-T. gondii em quatis habitantes do Parque Ecológico do Tietê, São Paulo, Brasil, pelo Teste de Aglutinação Modificada (MAT). No total, 99 amostras foram obtidas das quais $70,70 \%(\mathrm{n}=70)$ foram positivas para anticorpos anti-T. gondii, com títulos de anticorpos que variaram de 50 a 3200. Os dados obtidos neste estudo indicam que quatis sul-americanos são expostos a este parasito.

Palavras-chave: Sorologia. MAT. Vida selvagem. Toxoplasmose.

Correspondence to:

Sérgio Netto Vitaliano

Universidade de São Paulo, Faculdade de Medicina

Veterinária e Zootecnia, Departamento de Medicina

Veterinária Preventiva e Saúde Animal

Av. Prof. Dr. Orlando Marques de Paiva, 87, Cidade

Universitária, Butantã

CEP 05508-270, São Paulo, SP, Brazil

e-mail: sergiovitaliano@yahoo.com.br

Received: 12/02/2016

Approved: 01/06/2016

\section{Introduction}

Toxoplasma gondii is an intracellular protozoan parasite capable of infecting several animal species including humans (DUBEY, 2010). Its infection is widely prevalent worldwide, particularly in Brazil, where the prevalence of $T$. gondii infection in humans is especially high and can reach $100 \%$ in some areas (DUBEY et al., 2012). Domestic cats and other felids are definitive hosts (FRENKEL et al., 1970), and vir- 
tually all warm-blooded animals (birds and mammals) are intermediate hosts (DUBEY, 2010). Infection occurs after ingestion of food and/or water contaminated with oocysts from feces of infected cats or ingestion of undercooked meat containing tissue cysts from infected intermediate hosts (GENNARI et al., 2015).

Wildlife may play an important role in transmission and maintenance of $T$. gondii in the environment. However, only limited information on T. gondii circulating in wild animals is available in Brazil (YAI et al., 2009; DUBEY et al., 2011; PENA et al., 2011; CABRAL et al., 2013; CAÑÓN-FRANCO et al., 2013; VITALIANO et al., 2014a, 2014b).

The South American coati (Nasua nasua), also known as coatimundi, is a gregarious species within the family Procyonidae (which also include raccoons) and is widely distributed in South America (EMMONS; HELGEN, 2016). It occurs in Colombia, Venezuela, Guyana, Suriname, Peru, Bolivia, Argentina, Uruguay, Paraguay and Brazil (BITTNER et al., 2010), where it is often the most abundant species of the order Carnivora (GOMPPER; DECKER, 1998). Due to habitat losses, this species commonly lives in urban forests, traveling between wild and domestic areas (RODRIGUES et al., 2006).

South American coatis are medium-sized omnivorous animals that feed on fruit, small vertebrates and forest-floor invertebrates (GOMPPER; DECKER, 1998; ALVES-COSTA et al., 2004), occasionally consuming larger prey (REIS et al., 2006). There are also records of necrophagous diets and, in areas of anthropogenic influence, they are often observed feeding on garbage (RODRIGUES et al., 2006; CUNHA, 2010).

Procyonid species are reservoirs of several human and domestic animal pathogens. In Brazil, South American coatis are found naturally infected with different zoonotic parasites, such as Trypanosoma cruzi, Amblyomma cajennense (the main vector of Rickettsia rickettsii), Toxoplasma gondii and others (MINERVINO et al., 2010; ALVES et al., 2011; SILVA et al., 2014; WITTER et al., 2016). Despite their wide geographical distribution, relative abundance and etiological interest, most of the data concerning this species are focused only on its behavior and ecology (BEISIEGEL, 2001), whereas only a few studies have addressed infectious diseases (HERRERA et al., 2008; ALVES et al., 2011; SILVA et al., 2014).

Considering the scant information about $T$. gondii infection in South American coatis, the present study aimed to investigate the occurrence of antibodies against these parasites in a population of South American coatis living in Tietê Ecological Park, located inside the municipality of São Paulo, state of São Paulo, Brazil.

\section{Material and Methods}

Serum samples from 99 South American coatis

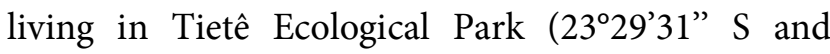
$\left.46^{\circ} 31^{\prime} 16^{\prime \prime} \mathrm{W}\right)$, in the municipality of São Paulo, were obtained. Blood was collected by means of jugular venipuncture during population control neutering routine campaigns, from September 2009 to February 2013. The sampled animals live in a situation of semicaptivity. The South American coati groups remain free inside the park, but nutritional support is offered daily.

Serum samples were assayed for the presence of anti-T. gondii antibodies by means of the modified agglutination test (MAT), using formalin-fixed, $\mathrm{RH}$ strain tachyzoites as the antigen. The samples were examined at dilutions of 1:25, 1:50 and 1:500. Titers of 1:25 or higher were considered indicative of $T$. gondii exposure. Positive samples were submitted to twofold serial dilutions to determine the final titer. The reading was made 12 hours after mixing the serum to the antigen. Display of a defined button at the base of the plate indicates a negative result, while the absence of the button or the formation of a complete carpet or a veil shape shows positive result (DUBEY; DESMONTS, 1987).

The association between gender, age and presence of antibodies against $T$. gondii were analyzed using the 
chi-square test, $\mathrm{P}$ values $<0.05$ were considered statistically significant (SPSS version 15.0, SPSS Inc., Chicago, IL, USA).

\section{Results}

Out of the total of 99 South American coatis, 70 (70.70\%) were seropositive for T. gondii. The antibody titers ranged from 25 to 3200 and the most prevalent titer was 400, observed in 19 samples (Table 1).

Table 1 - Titers of antibodies against Toxoplasma gondii (MAT $\geq 25$ ) in South American coatis (Nasua nasua) from Tietê Ecological Park - São Paulo, SP, Brazil - 2009-2013

\begin{tabular}{ccc}
\hline Titer & $\mathbf{N}^{\circ}$ of Animals & Occurrence (\%) \\
\hline 25 & 9 & 12.86 \\
50 & 16 & 22.86 \\
100 & 14 & 20.00 \\
200 & 9 & 12.86 \\
400 & 19 & 27.14 \\
800 & 2 & 2.86 \\
3200 & 1 & 1.42 \\
\hline Total & $\mathbf{7 0}$ & $\mathbf{1 0 0}$
\end{tabular}

Among the samples tested, 58 were from females, of which 45 (77.6\%) were positive; and 25 samples were from males, of which 14 (56\%) were positive for T. gondii antibodies (Table 2). In 16 samples, the gender was not identified: from this total, 11 samples (68.7\%) were positive.

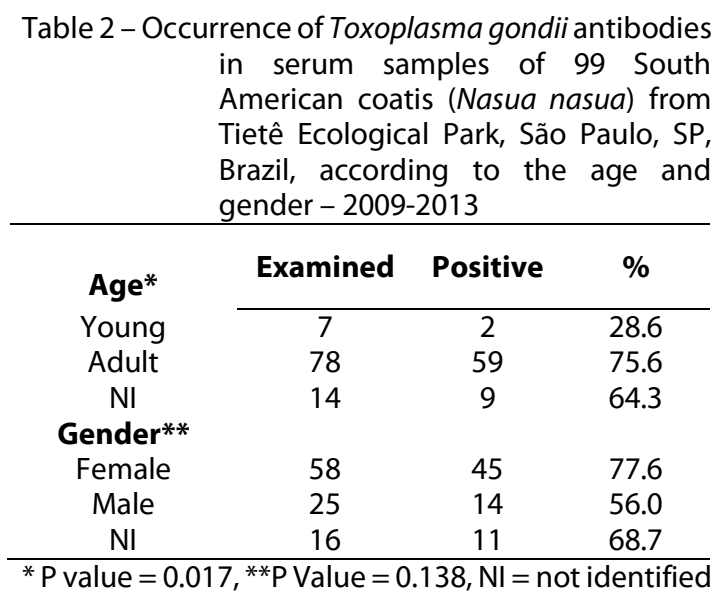

Seropositivity for T. gondii was strongly related to age, with positivity rates significantly higher $(\mathrm{p}=$ 0.017) among adult coatis (75.6\%) than among juvenile animals (Table 2).

\section{Discussion}

This study evaluated the presence of antibodies anti-T. gondii in a free-living population of South American coatis inhabiting Tietê Ecological Park, located in São Paulo municipality. Despite the freeliving condition of these coatis, they can be considered to be synanthropic since they were being fed with a complementary source of food (fruit) provided by the park administration. Furthermore, the park is located within an urban area.

Several studies have reported the presence of antibodies to T. gondii in wild procyonids (SOGORB et al., 1977; DUBEY et al., 1993; HANCOCK et al., 2005; MINERVINO et al., 2010). The results from the present study corroborate this information about the widespread presence of antibodies against $T$. gondii in Brazilian wildlife in general (VITALIANO et al., 2004; ANDRÉ et al., 2010; MINERVINO et al., 2010; VITALIANO et al., 2014). In the present study, $T$. gondii antibodies were found in $70.70 \%$ of the animals sampled. Similar prevalence rates were found in French Guiana in a study conducted from 1994 to 1995. Among all the South American coatis sampled in that study, $72 \%$ were seropositive for $T$. gondii antibodies (THOISY et al., 2003). In a T. gondii survey on captive animals in northern and northeastern Brazil, six out of 11 coatis presented antibodies against this parasite (MINERVINO et al., 2010).

As observed here, other Procyonidae species also present high frequency of seropositivity for T. gondii. In the USA, $84 \%$ of the raccoons tested (Procyon lotor) were found to be positive for T. gondii (HANCOCK et al., 2005). In another study, $100 \%$ of the 12 raccoons tested were seropositive for $T$. gondii antibodies (MITCHELL et al., 2006). The high frequency of seropositivity for T. gondii antibodies that are found in Procyonids, and more specifically in South American coatis, are related to their omnivorous feeding habits. Omnivores can become infected either through environmental contamination or through consumption of parasite-harboring prey. Another important feature that may influence the seropositivity to T. gondii in coatis is vertical usage of space. Terrestrial and/or 
terrestrial and arboreal species are more likely to become infected than are exclusively arboreal species because of the greater exposure of terrestrial species to feline feces than that of arboreal species. South American coatis have both arboreal and terrestrial habits and thus fit this exposure profile.

In the present study, the antibody titers ranged from 25 to 3200 . The titers observed here were higher than the titers found in captive South American coatis in northern Brazil, which ranged from 50 to 800 (PIMENTEL et al., 2009; MINERVINO et al., 2010).

The rates of seropositivity for T. gondii were seen to increase with age. As observed in previous studies on procyonids and other wild mammal species, this is a common pattern for many host species and disease agents. As animals age, their cumulative likelihood of exposure to T. gondii increases (ZARNKE et al., 2000; VITALIANO et al., 2004; HWANG et al., 2007). However, no influence of gender on T. gondii infection was observed in the present study.

The results from the current study indicate that $T$.

\section{References}

ALVES, F. M.; OLIFIERS, N.; BIANCHI, R. DE C.; DUARTE, A. C.; COTIAS, P. M.; D'ANDREA, P. S.; GOMPPER, M. E.; MOURÃO, G. M.; HERRERA, H. M.; JANSEN, A. M. Modulating variables of Trypanosoma cruzi and Trypanosoma evansi transmission in freeranging Coati (Nasua nasua) from the Brazilian Pantanal region. Vector-Borne and Zoonotic Diseases, v. 11, n. 7, p. $835-841,2011$. doi: 10.1089/vbz.2010.0096.

ALVES-COSTA, C. P.; FONSECA, G. A. B.; CHRISTÓFARO, C. Variation in the diet of the brownnosed coati (Nasua nasua) in southeastern Brazil. Journal of Mammalogy, v. 85, p. 478-482, 2004. doi: 10.1644/15451542(2004)085<0478:VITDOT>2.0.CO;2.

ANDRÉ, M. R.; ADANIA, C. H.; TEIXEIRA, R. H. F.; SILVA, K. F.; JUSI, M. M. G.; MACHADO, S. T. Z.; BORTOLLI, C. P. DE; FALCADE, M.; SOUSA, L.; ALEGRETTII, S. M.; FELIPPE, P. A. N.; MACHADO, R. Z. Antibodies to Toxoplasma gondii and Neospora caninum in captive Neotropical and exotic wild canids and felids. Journal of Parasitology, v. 96, n. 5, p. 10071009, 2010. doi: 10.1645/GE-2502.1.

BEISIEGEL, B. M. Notes on the coati, Nasua nasua gondii is endemic in the South American coati population in Tietê Ecological Park. Despite the high frequency of coatis presenting antibodies against $T$. gondii in South America, little is known about the pathogenicity of the parasite isolates found in this procyonid species. However, further studies should be developed in order to elucidate the real importance of these procyonids in the epidemiology of T. gondii.

\section{Acknowledgements}

The authors are grateful to the Brazilian National Research Council (Conselho Nacional de Pesquisa, $\mathrm{CNPq}$ ) and the Research Support Foundation of the State of São Paulo (Fundação de Amparo à Pesquisa do Estado de São Paulo, FAPESP) for financial support. Gennari, S. M. holds a grant from the National Research Council (Conselho Nacional de Pesquisa, CNPq), and Vitaliano, S. N. received financial support from FAPESP.

(Carnivora: Procyonidae) in an Atlantic forest area. Brazilian Journal of Biology, v. 61, n. 4, p. 689-692, 2001. doi:10.1590/S1519-69842001000400020.

BITTNER, G. C.; HANS, N. R.; NETO, G. H.; MORAIS, M. O.; FILHO, G. H.; HADDAD, V. Coati (Nasua nasua) attacks on humans: report. Wilderness and Environmental Medicine, v. 21, n. 4, p. 349-52, 2010. doi: 10.1016/j.wem.2010.09.005.

CABRAL, A. D.; GAMA, A. R.; SODRE , M. M.; SAVANI, E. S. M. M.; GALVA O-DIAS, M. A.; JORDA O, L. R.; MAEDA, M. M.; YAI, L. E. O.; GENNARI, S. M.; PENA, H. F. J. First isolation and genotyping of Toxoplasma gondii from bats (Mammalia: Chiroptera). Veterinary Parasitology, v. 193, n. 1, p. 100-104, 2013. doi: 10.1016/j.vetpar.2012.11.015.

CAÑÓN-FRANCO, W. A.; ARAÚJO, F. A.; LÓPEZOROZCO, N.; JARDIM, M. M. A.; KEID, L. B.; DALLAROSA, C.; CABRAL, A. D.; PENA, H. F.; GENNARI, S. M. Toxoplasma gondii in free-ranging wild small felids from Brazil: molecular detection and genotypic characterization. 
Veterinary Parasitology, v. 197, n. 3-4, p. 462-469, 2013. doi: 10.1016/j.vetpar.2013.07.019.

CUNHA, A. A. Negative effects of tourism in a Brazilian Atlantic forest National Park. Journal for Nature Conservation, v. 18, n. 4, p. 291-295, 2010. doi: 10.1016/j.jnc.2010.01.001.

DUBEY, J. P.; DESMONTS, G. Serological responses of equids fed Toxoplasma gondii oocysts. Equine Veterinary Journal, v. 19, p. 337-339, 1987. doi: 10.1111/j.20423306.1987.tb01426.x.

DUBEY, J. P.; HAMIR, A. N.; SHEN, S. K.; THULLIEZ, P.; RUPPRECHT, C. E. Experimental Toxoplasma gondii infection in raccoons (Procyon lotor). The Journal of Parasitology, v. 79, p. 548-552, 1993.

DUBEY, J. P. Toxoplasmosis of animals and humans. Boca Raton: CRC Press, 2010. 318 p.

DUBEY, J. P., LAGO E. G., GENNARI S. M., SU C., JONES J. L. Toxoplasmosis in humans and animals in Brazil: high prevalence, high burden of disease, and epidemiology. Parasitology, v. 139, n. 11, p. 1375-1424, 2012. doi: $10.1017 /$ S0031182012000765.

DUBEY, J. P.; VELMURUGAN, G. V.; RAJENDRAN, C.; YABSLEY, M. J.; THOMAS, N. J.; BECKMEN, K. B.; SINNETT, D.; RUID, D.; HART, J.; FAIR, P. A.; MCFEE, W. E.; SHEARN-BOCHSLER, V.; KWOK, O. C.; FERREIRA, L. R.; CHOUDHARY, S.; FARIA, E. B.; ZHOU, H.; FELIX, T. A.; SU, C. Genetic characterization of Toxoplasma gondii in wildlife from North America revealed widespread and high prevalence of the fourth clonal type. International Journal for Parasitology , v. 41, n. 11, p. 1139-1147, 2011. doi: 10.1016/j.ijpara.2011.06.005.

EMMONS, L.; HELGEN, K. Nasua nasua. In: IUCN (International Union for Conservation of Nature) 2016. IUCN red list of threatened species. doi: 10.2305/IUCN.UK.2016-1.RLTS.T41684A45216227.en.

FRENKEL, J. K.; DUBEY, J. P.; MILLER, N. L. Toxoplasma gondii in cats: fecal stages identified as coccidian oocysts. Science, v. 167 , n. 3919 , p. $893-896$, 1970. doi: 10.1126/ science.167.3919.893.

GENNARI, S. M.; ESMERIN, P. O.; LOPES, M. G.; SOARES, H. S.; VITALIANO, S. N.; CABRAL, A. D.; PENA, H. F. J.; HORTA, M. C.; CAVALCANTE, P. H.; FORTES, K. P.; VILLALOBOS, E. M. C. Occurrence of antibodies against Toxoplasma gondii and its isolation and genotyping in donkeys, mules, and horses in Brazil. Veterinary Parasitology, v. 209, n. 1-2, p. 129-132, 2015. doi: 10.1016/j.vetpar.2015.01.023.

GOMPPER, M. E.; DECKER, D. M. Nasua nasua. Mammalian Species, n. 580, p. 1-9, 1998. doi: 10.2307/ 3504444.

HANCOCK, K.; THIELE, L. A.; ZAJAC, A. M.; ELVINGER, F.; LINDSAY, D. S. Prevalence of antibodies to Toxoplasma gondii in raccoons (Procyon lotor) from an urban area of Northern Virginia. Journal of Parasitology, v. 91, n. 3, p. 694695, 2005. doi: 10.1645/GE-443R.

HERRERA, H. M.; LISBOA, C. V.; PINHO, A. P.; OLIFIERS, N.; BIANCHI, R. C.; ROCHA, F. L.; MOURÃO, G. M.; JANSEN, A. M. The coati (Nasua nasua, Carnivora, Procyonidae) as a reservoir host for the main lineages of Trypanosoma cruzi in the Pantanal region, Brazil. Transactions of the Royal Society of Tropical Medicine and Hygiene, v. 102, n. 11, p. 1133-1139, 2008. doi: 10.1016/j.trstmh.2008.04.041.

HWANG, Y. T.; PITT, J. A.; QUIRK, T. W.; DUBEY, J. P. Seroprevalence of Toxoplasma gondii in mesocarnivores of the Canadian prairies. Journal of Parasitology, v. 93, n. 6, p. 1370-1373, 2007. doi: 10.1645/GE-1319.1.

MINERVINO, A. H. H.; SOARES, H. S.; BARRÊTOJÚNIOR, R. A.; NEVES, K. A. L.; JESUS PENA, H. F.; ORTOLANI, E. L.; DUBEY, J. P.; GENNARI, S. M. Seroprevalence of Toxoplasma gondii antibodies in captive wild mammals and birds in Brazil. Journal of Zoo and Wildlife Medicine, v. 41, n. 3, p. 572-574, 2010. doi: 10.1638/2010-0046.1.

MITCHELL, S. M.; RICHARDSON, D. J.; LINDSAY, D. S. Prevalence of agglutinating antibodies to Toxoplasma gondii in striped skunks (Mephitis mephitis), opossums (Didelphis virginiana), and raccoons (Procyon lotor) from Connecticut. Journal of Parasitology, v. 92, n. 3, p. 664665, 2006. doi: 10.1645/GE-800R.1.

PENA, H. F.; MARVULO, M. F.; HORTA, M. C.; SILVA, M. A.; SILVA, J. C.; SIQUEIRA, D. B.; LIMA, P. A.; VITALIANO, S. N.; GENNARI, S. M. Isolation and genetic characterisation of Toxoplasma gondii from a red-handed howler monkey (Alouatta belzebul), a jaguarundi (Puma yagouaroundi), and a black-eared opossum (Didelphis aurita) from Brazil. Veterinary Parasitology, v. 175, n. 3, p. 377-381, 2011. doi: 10.1016/j.vetpar.2010.10.015.

PIMENTEL, J. S.; GENNARI, S. M.; DUBEY, J. P.; MARVULO, M. F. V.; VASCONCELLOS, S. A.; MORAIS, 
Z. M.; SILVA, J. C. R.; NETO, J. E. Inquérito sorológico para toxoplasmose e leptospirose em mamíferos selvagens neotropicais do Zoológico de Aracaju, Sergipe. Pesquisa Veterinária Brasileira, v. 29, n. 12, p. 1009-1014, 2009. doi: 10.1590/S0100-736X2009001200010.

REIS, N. R.; PERACCHI, A. L.; PEDRO, W. A.; DE LIMA, I. P. Mamíferos do Brasil. Londrina, 2006. 437 p.

RODRIGUES, A. F. S. F.; DAEMON, E.; MASSARD, C. L. Ectoparasites of Nasua nasua (Carnivora, Procyonidae) from an urban forest in Southeastern Brazil. Arquivo Brasileiro de Medicina Veterinária e Zootecnia, v. 58, n. 5, p. 969-971, 2006. doi: 10.1590/S0102-09352006000500043.

SILVA, R. O. S.; DE ALMEIDA, L. R.; JUNIOR, C. A. O.; SOARES, D. F. M.; PEREIRA, P. L. L.; RUPNIK, M.; LOBATO, F. C. F. Carriage of Clostridium difficile in freeliving South American coati (Nasua nasua) in Brazil. Anaerobe, v. 30, p. 99-101, 2014. doi: 10.1016/j.anaerobe. 2014.09.012.

SOGORB, F. S.; JAMRA, L. F.; GUIMARÃES, E. C. Toxoplasmose em animais de São Paulo, Brasil. Revista do Instituto de Medicina Tropical de São Paulo, v. 19, p.191-194, 1977.

THOISY, B.; DEMAR, M.; AZNAR, C.; CARME, B. Ecologic correlates of Toxoplasma gondii exposure in freeranging neotropical mammals. Journal of Wildlife Diseases, v. 39, n. 2, p. 456-459, 2003.

VITAliANO, S. N.; SILVA, D. A. O; MINEO, T. W. P.; FERREIRA, R. A.; BEVILACQUA, E.; MINEO, J. R. Seroprevalence of Toxoplasma gondii and Neospora caninum in captive maned wolves (Chrysocyon brachyurus) from southestern and midwestern regions of Brazil. Veterinary Parasitology, v. 122, p. 253-260, 2004. doi: 10.1016/j.vetpar.2004.04.004.

VITALIANO, S. N.; SOARES, H. S.; MINERVINO, A. H. H.; SANTOS, A. L. Q.; WERTHER, K.; MARVULO, M. F. V.; SIQUEIRA, D. B.; PENA, H. F. J.; SOARES, R. M.; SU, C.; GENNARI. S. M. Genetic characterization of Toxoplasma gondii from Brazilian wildlife revealed abundant new genotypes International Journal for Parasitology: Parasites and Wildlife, v. 3, n. 3, p. 276-283, 2014a. doi: 10.1016/j.ijppaw.2014.09.003.

VITALIANO, S. N.; SOARES, H. S.; PENA, H. F. J.; DUBEY, J. P.; GENNARI. S. M. Serologic evidence of Toxoplasma gondii infection in wild birds and mammals from Southeast Brazil. Journal of Zoo and Wildlife Medicine , v. 45, n. 1, p. 197-199, 2014b. doi: 10.1638/2013-0179R.1.

WITTER, R.; MARTINS, T. F.; CAMPOS, A. K.; MELO, A. L. T.; CORRÊA, S. H. R.; MORGADO, T. O.; WOLF, R. W.; MAY-JÚNIOR, J. A.; SINKOC, A. L.; STRÜSSMANN, C.; AGUIAR, D. M.; ROSSI, R. V.; SEMEDO, T. B. F.; CAMPOS, Z.; DESBIEZ, A. L. J.; LABRUNA, M. B.; PACHECO, R. C. Rickettsial infection in ticks (Acari: Ixodidae) of wild animals in midwestern Brazil. Ticks and Tick-borne Diseases, v. 7, n. 3, p. 415-423. doi: 10.1016/j.ttbdis.2015.12.019.

YAI, L. E. O.; RAGOZO, A. M.; SOARES, R. M.; PENA, H. F.; SU, C.; GENNARI, S. M. Genetic diversity among capybara (Hydrochaeris hydrochaeris) isolates of Toxoplasma gondii from Brazil. Veterinary Parasitology, v. 162, n. 3, p. 332-337, 2009. doi: 10.1016/j.vetpar.2009.03.007.

ZARNKE, L.; DUBEY, J. P.; KWOK, O. C.; VER HOEF, J. M. Serologic survey for Toxoplasma gondii in selected wildlife species from Alaska. Journal of Wildlife Diseases, v. 36 , n. 2, p. 219-224, 2000. doi: 10.7589/0090-355836.2.219. 